\title{
Chapter 2: Mitosz as a Public Speaker and Popularizer of Polish Culture in the USA
}

As an officer of the Consulate, Miłosz was assigned the task of maintaining relations with Poles living abroad, building a favorable image of Poland, and later - upon assuming the post of second secretary at the Embassy in Washington - organizing events, developing contacts with academic and artistic circles, and participating in American and Polish educational and cultural events. These duties involved giving public talks to various audiences.

The poet's relations with the Polish diaspora were marked by reserve and distrust. This was especially true of post-war émigrés, who did not recognize the government in Warsaw, and boycotted the activities of its diplomacy. ${ }^{144}$ Establishing closer relations with this group was hampered by Miłosz's divergent attitude toward pre-war Poland. Perhaps the sharpest comment regarding this polarization of positions is found in the note he wrote on New Year's Eve, 1945:

\begin{abstract}
That New Year's Eve was a descent into hell, into the bottom of a historical nightmare; I drank and behaved like a buffoon in order to extinguish thought, but in vain; my consciousness was clear and, unable to cope with such a grotesque situation, turned it into a tormenting nightmare. Eternal Polishness, the Polish manor, Nawłoć ${ }^{145}$ one minute before the day of reckoning, before its disappearance forever, and I, with my shame and my ambition to escape from the manor, thrust back into it once again as a sign that, like it or not, here is where I belong, that I had tried in vain to escape from the traditionalism that I disliked and the religion of absolutized values. A Dante of Sarmatia was needed to portray a scene from this Finis Poloniae (A Year of the Hunter, 89).
\end{abstract}

In time, the poet managed to convince some people about his initiatives, but - as he reports - he was supported only confidentially. Officially, for fear of ostracism, very few would openly back the activities of the Consulate or the Embassy. The cooperation of people and institutions with the communists could attract severe criticism, as was the case with the Kosciuszko Foundation, involved in organizing academic exchange. After several years, Miłosz recalled that he found it easiest to move in the circles of émigrés with Jewish roots, who shared his assessment of the political possibilities in Europe, and among his old friends from Wilno. The diplomat was critical of wartime castaways who tried to recreate the capital's literary salon culture - already in $A$

144 On this see the essay by Lukas, Richard C.: "Polish Americans and the Polish Questions" in his book Bitter Legacy: Polish-American Relations in the Wake of World War II, Lexington, Kentucky: The University Press of Kentucky, 1982, pp. 119-138.

145 In Stefan Żeromski’s novel Przedwiośnie [The Spring to Come, 1925], Nawłoć is a manor, presented satirically as the epitome of the gentry's carefree life, in contrast to the miserable life of the peasants.) Żeromski (1864-1925) was a prominent Polish novelist and dramatist. 
Year of the Hunter he explained the reasons for his distrust of the romantic myth of emigration. Even before making a decision to break ties with Warsaw, as he recalled. He did not consider joining the post-war émigré community in the US:

At that time, both Jan Lechoń and Kazimierz Wierzyński were living in New York. Ultimately, I could have beaten my chest in contrition and would have been accepted, but it was probably not merely pride that prevented me from taking my walk to Canossa. Besides, I was aware of what the writing émigrés were living on. Their source of income was the Cold War, and institutions such as Free Europe enjoyed the privileges of a monopolist (Zaraz po wojnie [Right after the War] 592).

However, what Miłosz then criticized, he deeply cared about, and was moved by it:

No other nation has managed to get into a similar situation, with several hundred thousand soldiers abroad who do not want to return. Their fate will be the fate of the Russian emigration, not for the same reasons - since Russian émigrés fought against the revolution, and the Poles fought to defend their homeland against fascism. They will be taxi drivers in Uruguay, overseers of copper mines in Africa, waiters in Paris and they will waste away in nostalgia. Here in New York, I met my university friend who is "uncompromising." He is a lawyer and speaks English, French, Spanish and German fluently, and these skills have helped him to become a senior waiter in a New York hotel. The wife also works so that they can stay afloat, the child is in a nursery and cannot speak Polish anymore. And how many of these people will even get to the United States? ${ }^{146}$

Due to the distance separating Miłosz from these circles, and due to consular duties, he was pushed toward the Polish diaspora originating from the economic emigration of the 18th and 19th centuries, now residing in the industrial cities of the East Coast and in central states. The poet would write about them in his letters, reports, articles and editorials. He would talk of traditionalism, the mentality of old peasants and current laborers, the long road to social advancement, political passivity, life in the social lowlands due to poor education - this image is consistent with how Nelson Algren described the lives of Poles in Chicago in The Man with the Golden Arm.

146 Miłosz, Czesław: "Polska z Nowego Yorku" [Poland form New York City], Polska wyzwolona (Buenos Aires) 1946, issue 66, p. 6 and Przekrój 1946, issue 66, pp. 7-8. Janta-Połczyński remarked: "Let us, in turn, call to mind England. In Poland it is a very painful subject. I already mentioned the reactions to Churchill, as an advocate of Western morality. An additional, complementary factor in relation to Great Britain as an ally is the circumstance that almost all repatriated former soldiers of the Polish Army in the West express deep resentment towards England's stance vis-à-vis the Polish cause, and towards the treatment they themselves received. (...) As for this revolution in Polish views of other countries, it took place most visibly in relation to England, as compared with the other wartime allies. This is because somewhere, at the bottom of their souls, there lies, not always justified, but nonetheless a very important sense of having been deeply wronged by the English.” In JantaPołczyński, Aleksander: Wracam z Polski [Returning from Poland], op. cit., pp. 181-182. 
Even though the diplomat often visited Polish émigrés, we know of these meetings mostly from reports and letters.

We do not know how long Miłosz's visits lasted, whether they were official in tone, or accompanied by informal conversations, nor do we know if the speaker only presented the text, or if he made unscripted comments that were not included in the remaining official records. We will never know who asked questions, if any, and what they were, how the speaker responded, or even the extent to which he was involved in any discussions that may have ensued. We cannot recreate the atmosphere of the lectures, nor ascertain how the diplomat was received in the circles of pre-war and post-war émigrés. We do not know how, or even if, his words were understood. We may analyze the texts of the talks today in isolation from their historical context and interpersonal contacts. Only Elizabeth Kridl Valkenier noted:

As a cultural attaché, Miłosz was eager to speak in public on Polish literature or culture, and my father arranged for him to lecture at Smith College, where he taught at the time. I well remember one appearance in Northampton in 1947. Since Miłosz gave his talk in Polish, the audience consisted almost entirely of Polish American farmers from the neighborhood. The lecture did not go well. Some in the audience objected that the speaker concentrated on post-World War I innovative writers and failed to mention Henryk Sienkiewicz - a nineteenth-century author of popular historical novels with stirring descriptions of seventeenth-century Polish military exploits. Miłosz did not take that criticism kindly, and in the privacy of our home, he fulminated against the narrow-minded ignorance of the little peasants. (...)

He showed no more forbearance for our American friend Virginia Pickett, who offered to put up Miłosz and his first wife, Janka, during another lecture at Smith. A college graduate and well-off member of local society, Virginia tried to entertain the poet with some appropriately "elevated intellectual" conversation, steering their talk to some well-known names in music or literature. Again, rather than take this incident lightly and see its comical aspects, Miłosz expostulated to us on Virginia's attempts at "cultured talk" as unbearable middle-class pretense and banality (Invisible Rope, 12-13).

More can be said about Miłosz's impressions of his visits in Polish émigré centers, as they produced more than comments in letters or official reports. These visits were also discussed in special memoranda, with which Miłosz tried to induce others to take actions he believed to be necessary.

The main sources we have at our disposal are manuscripts or typescripts of speeches that Miłosz gave. Because they usually do not contain information on the time, place and audience, it is not easy to arrange them in chronological order, and thus discover possible links between them. Based on their content, it is sometimes possible to determine the year of their composition and presentation, for example, when Miłosz mentions the latest books, Sprzysiężenie [The Pact] by Jerzy Kisielewski, Jezioro Bodeńskie [Lake Constance] by Stanisław Dygat, or the US edition of Smoke 
over Birkenau by Seweryna Szmaglewska. There are more unknowns: first and foremost - the context. In what circumstances did the diplomat prepare the lectures, how long did he work on them, which did he use more than once, when and for what reasons? Typescripts in English contain shared content, and shorter pieces are sometimes woven into longer ones. This would mean that the author intended the first ones as small speeches or that, over time, he built larger wholes, merging his older thoughts. Presumably, Miłosz considered the issue of how to combine informing with influencing, and who the listeners were and how to reach them. Judging by the surviving texts of "Dzieci Europy" [Children of Europe] ${ }^{147}$ and "Odczyt o literaturze wygłoszony na Columbia University 18 IV 1949 r.” [My subject is post-war literature in Europe...], ${ }^{148}$ it does not seem that he treated these issues as a matter of priority.

Whoever read Miłosz - writes Marta Piwińska in reference to Mickiewicz - knows. So I can only add that the Visions from San Francisco Bay, sketches about the "agony of the West," the story of American roads, and California as "the last place" seem as if they were a continuation the Paris lectures..$^{149}$

Equally, if not more, they also seem to be a continuation of his American lectures and journalistic writing from the 1940s. From the notes made by Manfred Kridl it is known that the poet's first talk, a lecture on underground literature, was delivered on April 27, 1946, at the New York Public Library, which his teacher from Wilno preceded with a speech. While Kridl's text has survived, ${ }^{150}$ the talk itself did not. Chronologically, the first preserved lecture is the text of "Dzieci Europy."

\section{“Dzieci Europy" [Children of Europe]}

The lecture "Children of Europe," although this is not confirmed by the available sources, may have been delivered at the ceremony commemorating the outbreak of the Warsaw Ghetto Uprising. In it, Miłosz talked about events and phenomena that,

147 Miłosz, Czesław: "Dzieci Europy” [Children of Europe]. Typescript, not dated, Beinecke Library, Box 114, Folder 1624.

148 Miłosz, Czesław: “Odczyt o literaturze wygłoszony na Columbia University 18 IV 1949 r.” [My subject is post-war literature in Europe...] Typescript, no title or date, Beinecke Library, Box 125, Folder 1973. Beinecke Library, Box 156, Folder 2465].

149 Piwińska, Marta: "Prelekcje o Polsce dla Zachodu. Mickiewicz - Miłosz." [Talks on Poland for the West. Mickiewicz - Miłosz]. In Poznawanie Miłosza 2 [Appreciating Miłosz 2], Part Two 1980-1998, op. cit., p. 80.

150 Kridl, Manfred: "Introductory speech preceding the talk of Czesław Miłosz on underground literature, New York Public Library, 27. IV. 46.” Manfred Kridl Collection, Columbia Rare Book and Manuscript Library, Box 8, Lecture Notes (Miscellaneous). 
to a Pole living under Hitler's occupation, were either part of everyday life or common knowledge. He starts with how, starting in the summer of 1943, he fed two Jewish boys who survived the Ghetto Uprising. He explains what the Jewish quarter was, how the transports of Jews to Auschwitz ended, and how the gas chambers at Auschwitz worked. He talks about the price of death that Poles paid for helping Jews, and describes German gendarmes rounding up some boys, after which no one saw them ever again. He presents the figure of a certain janitor, who threatened to denounce him to the Gestapo for feeding them, but who knew that an illegal printing house was operating in the building, so he remained silent, fearing the judgment of the underground state. Miłosz reports on the kinds of games the youngest played, imitating arrests, roundups and scenes from life in a concentration camp. The relationship is interwoven with digressions meant to encourage empathy and compassion:

What is the "normal" world to a person? It is the world that we get used to in childhood. To these children, round-ups and concentration camps were institutions as normal as baseball and movies would be to American children. I asked myself in fear if these children would not consider round-ups and concentration camps to be the easiest ways of resolving political disputes.

I worried about the early political awareness of children and the heroism with which they died in the name of their homeland. Reports from various European countries cite numerous examples of boundless sacrifices made by teenage boys and girls. These reports do not lie. However, whoever wants a harmonious type of human to arise, developed comprehensively, not one-dimensionally, must demand that a certain age limit be set from which the passions of martial arts befitting adults are allowed to the young. There was no such limit in Europe, and when twelve-year-olds become soldiers, this means that the balance of societies in which it happens is utterly disrupted and it will take a long time to restore it. ${ }^{151}$

Miłosz explains what the scouting resistance movement was about, and minor sabotage; he talks about the participation and death of children in the Warsaw Uprising. He talks about child labor, ranging from children being involved innocent but risky activities, such as collecting donations for performing anti-Nazi songs in a streetcar, to downright dangerous and corruptive ventures, such as currency trading, smuggling and fencing:

In this environment, the children were learning cool realism, cunning, and absence of scruples. Their ability to calculate and their knowledge of exchange rates were truly stunning. There were young men, whose place should have been in the school bench, dressed elegantly in loose jackets reaching almost to their knees - such was the latest European fashion between 1939-1945. Their pockets bulged with excess banknotes; their fingers were decorated with gold rings. The elders were looking on with sadness - yes, but the young man brought money home. The families lived a difficult life: each day, their members set out into the city as an animal goes out hunting - they did the hunting, and they were hunted. Will he be back or won't he? With loot or with nothing? Only this mattered..$^{152}$

151 Miłosz, Czesław: "Dzieci Europy” [Children of Europe], op. cit., p. 7.

152 Ibidem, p. 9. 
The author discusses orphanhood and wartime homelessness, wandering, death by starvation, and child trafficking. The talk ends with a description of the failures in raising the youngest survivors of the war:

One of my friends brought from Warsaw two of his sons, aged eight and nine. When they were at home, their first question was, "How much does a kilogram of meat cost?" They told them the price, and the second matter-of-fact question was asked immediately: "With bone or without?" Their attitude to the new country in which they found themselves was completely down-to-earth, sober, and they were not to be bothered with skyscrapers, neon lights and the multitude of cars (...)

Someone else, who brought his thirteen-year-old niece from Warsaw to London after her parents died, wrote to me: "I must admit that my wife and I are constantly embarrassed. This child is an old, experienced woman; she looks at us with eyes that have seen too much, and we cannot bring ourselves to send her to school, to be among giddy girls." 153

The end of the talk reveals the concept on which it was built. This is the thought that the poet shared with Tadeusz Różewicz, expressed in the poem "Lament."

Miłosz's account is deliberately modeled somewhat on Różewicz’s style. It presents facts that are known to Poles, but are new and shocking to the listeners. The advantage of experience allows him to choose the simplest and most suggestive narration: restrained testimony, cool, precise reporting. The poet knows that this is sufficient. The shock of the recipient arises from a confrontation with inconceivable experiences and this is the shock he aims for. The implicit context of his talk is firstly the trauma of war, and secondly, the thought he often repeated about the absence of a sense of history in Americans, their lack of awareness of what went on in Europe during the Nazi period. ${ }^{155}$ Also in the talk, he makes this indictment:

To millions of people, politics has hitherto been a highly vague field, devoid of any relation to their daily work and play. To these two, as to a huge number of people in Europe, it was what it really is: a matter of life or death. ${ }^{156}$

153 Ibidem, pp. 10-11.

154 See Różewicz, Tadeusz: “Lament.” In Różewicz, Tadeusz: Niepokój. Wybór wierszy, [Anxiety - a selection of poems] Warsaw, 2000, p. 9. In 1948 Miłosz translated to English Tadeusz Różewicz’s poems "Róża” [Rose], "Oczyszczenie” [Cleansing] and "Lament” [Lament]. Manuscripts of these translations are kept in the Beinecke Library, Box 145, Folder 2285.

155 Miłosz never mentioned whether he knew the essay by Hannah Arendt in which she used the term "banality of evil." See Arendt, Hannah: “German Guilt.” In Essays of Understanding: 1930-1954. Edited by Jerome Kohn, New York: Harcourt, Brace and Company, 1954.

156 Miłosz, Czesław: "Dzieci Europy” [Children of Europe], op. cit., p. 4. 
Not often did the poet express these sentiments in his poems, nor did it make any sense to rub salt in the wounds in his letters, upsetting relations with those who had been similarly affected by the war. In America, as he was unable to express the trauma he experienced, the trauma only intensified, to the point of turning into passion, which manifested also a prosecutor's passion. In the content and form of the talk, Miłosz shows a type of fortitude, a grim bravery, putting himself above his audience. However, he does not stop there. His intention is not so much to remove the veil from the eyes of his listeners, but to stimulate their sense of joint responsibility and brotherhood.

Miłosz does not build a monument to national heroism, he is also far from psychologizing. His relation to people's behavior meets the requirements of a behaviorist description. He speaks of everyday heroism and cowardice, of the regularity and inevitability of wartime fate:

It is very difficult to show this European upbringing for what it really was. There is always a tendency in us to speak separately about heroism, separately about depravation, and to divide people into black and white characters. In fact, courage, dedication, insensitivity and cunning are often intertwined and cannot be separated. ${ }^{157}$

And that is why he makes intellectual and moral demands, speaking not as partner, but rather as a mentor. This imposes thinking in global terms, and takes away the comfort of one's conviction about the local significance of history. Miłosz roots out the shallow mythologizing evident in common clichés:

One world or none ${ }^{158}$ It is a pity that more and more worlds are being created. Those who think that the nations of Europe can be "tamed" merely by giving them (if giving is the operative word) injections of money and food - we, people from Europe, perceive things as those who would like to grow corn in the greenhouse. In history, greenhouses are not possible. Who once set foot on a path of tough, bloody experiences that every one of us would be glad to spare the human race, shall continue on this path. ${ }^{159}$

Balancing on one side of the scale the dangers of the recent and still possible use of nuclear weapons, and on the other - those resulting from the emergence of a new mindset of people wounded by war, Miłosz does not hesitate:

157 Ibidem, p. 8.

158 This was the title of the report that the Federation of American Scientists published in March 1946. A book of 86 pages, it consisted of essays by scholars and intellectuals (including Albert Einstein, Julius Robert Oppenheimer, Walter Lippman, with a preface written by Niels Bohr). It was critical of the deployment of the atom bombs in Hiroshima and Nagasaki; it was also the first collective appeal for imposing international control over political use of nuclear weapons. Soon after its publication, it became a subject of numerous discussions, and one of the bestselling books of 1946.

159 Miłosz, Czesław: "Dzieci Europy" [Children of Europe], op. cit., p. 11. 
Yes, we are embittered. We have seen cities of millions which were depopulated within a month, and then served as capitals for rats; children who were drowned in pools with stones tied to their necks, we saw young generations that were hateful, zealous, heroic, ironic, and cunning. Our imagination is weary. We have crossed the line of shadow. We look at the atom bomb with indifference. Let those who have more to lose worry about it. We too have deliberated on peace. ${ }^{160}$

Miłosz's words seem to be a paraphrase of a fragment of the poem "Ocalony" [Rescued]. Aleksander Janta-Połczyński presented a similar position:

I once talked to John Hersey, the author of a reportage about Hiroshima, who was in Warsaw as one of the first American journalists, after the "liberation," and I asked him what made the greater impression on him: Hiroshima or Warsaw? There was no doubt in his mind that it was Warsaw. At least because - as he put it - the destruction of Hiroshima took place within a fraction of a second, but in Warsaw it lasted for many long months. It is as if he wanted to emphasize that the reaction to these two most horrible acts of destruction of the latest war must be measured not so much in images of ruined houses and shattered stones, but in the experience of the people enduring the collapse of their world. When comparing these two horrors, it is necessary to take into account their duration. Death is not terrible; what is terrible is dying. Hiroshima fell struck by a lightning, while Warsaw lay dying until the very last round banged into her walls, tugging at the hearts of the remaining people. And that is the sole standard by which to measure her fate. ${ }^{161}$

"Dzieci Europy" [Children of Europe] is a prose rendition of the poem "Dziecię Europy" [Child of Europe]. The text of the talk and the poem were written in the same year, and the text in prose is an expanded explanatory note of sorts to the anticatechism written in verse. In both, the more the author suppresses his emotions, the more he fumes and boils. In the poem, the principles of anti-pedagogy are delineated with such cold precision that - as Dante might have put it - so cold are they that they burn. The talk is different: Miłosz gives in to a sense of powerlessness, horrified by thinking about the future. It is possible that the talks were the only situations in which he allowed himself such a cathartic disclosure of despair.

\section{Articles and Talks in English until 1947}

In his talks, Miłosz consistently equates being Polish with being European. His starting point is the idea of Poland as part of the civilization of the Old Continent. He expects this perspective to be accepted and treated as the only and obvious one. ${ }^{162}$

\footnotetext{
160 Ibidem, p. 11.

161 Janta-Połczyński, Aleksander: Wracam z Polski [Returning from Poland], op. cit., p. 25.

162 Marta Piwińska says this on Mickiewicz and Miłosz: "And thus their talks are not a humiliating nationalist ceremony, proving that we rightfully deserve our citizenship in the family on nations, since we gave the world Copernicus and Chopin, and since we successfully passed the exam during the Renaissance and in the era of surrealism. For them it is different: we have the right to a citizenship
} 
In the meetings with Polish-speaking audiences, the speaker could refer to some knowledge, or memory, even if it was the memory of national myths or the history of an imagined community; ${ }^{163}$ there was a minimal plane, also linguistic and conceptual, on which certain issues could be articulated. ${ }^{164}$ With English-speaking audiences, the poet encountered at least two additional complications: how to formulate theses without Polish maxims, terms, symbols, metaphors, or key words, and then how to capture his thoughts in the rhetorical structure adopted in English-language literature and - what is most troublesome - how to talk about the history and culture of a country the listeners know nearly nothing about, or are satisfied with a stereotype. These dilemmas concern both the texts delivered in public and the articles published in the bulletin Poland of Today. What is more, he faced the same problem from the opposite side - similar concerns were raised by writing about America and Americans for the Polish press. How to translate into Polish a phenomenon that is much more accurately expressible English? How to discuss issues that are known less and less behind the Iron Curtain? Once again - and this time permanently - Miłosz faces the difficulties of intercultural translation, its possibilities, mechanisms and limitations, and the problem of memory, whose construction was the subject of various policies in Europe and America. His attitude is well described in the later concept of a "migrant intellectual," proposed by Edward W. Said, who was defined "a person engaged in rethinking and reformulating the historical experience of his own nation with the view to bringing diverse groups closer together."165

Miłosz's talks in English illustrate his effort to construct a new message about Poland and Polishness. Their author moves between competing ways of addressing these subjects. The first of these, the American way, grows out of his observations of the old emigration, the new emigration, and the policies of the Stalinist government: it is often a mixture of journalistic clichés. The second is the official way, based on negating the past and glorifying the present, is the language of propaganda. The third, the way of the conservative Polish community, is at times founded on resentment and a cult of national sacrifice, incomprehensible from the American perspective. Miłosz understands that it is necessary to compose a message that is as independent

in the overall human culture, as without us it would be incomplete. We bring unique values - so to say - in competition to the West," op. cit., p. 73.

163 See Anderson, Benedict: Imagined communities: reflections on the origin and spread of nationalism. London and New York: Verso Books, 1991.

164 The poet also commented on this situation later, as a lecturer at Berkeley: "a professor, before weaning himself from Polish audiences, is unable to speak to foreigners. Myths rooted in the language, reverberating in one’s emotions, are dead to them.” In Miłosz, Czesław: "O historii polskiej literatury wolnomyślicielskiej i masonach" [On the history of Polish Freemason literature and the Freemasons]. In Miłosz, Czesław: Prywatne obowiazki [Private Obligations], Krakow, 2001, p. 153.

165 Karwowska, Bożena: “Czesław Miłosz i jego anglojęzyczni czytelnicy” [Czesław Miłosz and his English-language Readers], Ruch Literacki 2011, issue 3, p. 262. 
as possible from anyone else. This is the moment when, for the first time, he proposes a thoroughly new outlook, recontextualizing his reflection on Poland and Polishness. This separate way is of significant value in terms of identity: the poet determines that his identity is in relation to foreigners, but he must also confront the beliefs foreigners hold in relation to him as a Pole, and a Slav. The re-construction of Poland and Polishness in lectures becomes a way of re-constructing his own identity.

The English-language manuscripts contain deletions and handwritten corrections by the author and by two other people, probably more fluent in English. It is not known how the speaker negotiated the content of the readings with his superiors, in what way he applied for their approval, and whether he was assigned specific topics for his talks. A comparison of his English-language talks with the articles published in Poland of Today suggests that Miłosz, as a speaker, enjoyed much greater freedom in English.

\section{The Articles in Poland of Today}

In 1946, the Embassy's bulletin Poland of Today featured Miłosz’s essays, "Literature in Poland Today"166 "Renaissance of the Polish Theatre"167 and "American Authors and Their Polish Public."168 In 1947, the article "Intellectual Revival in Post-War Poland"169 was published there, and another, titled "Literature in Poland"170, in 1948. They are all accompanied by a biographical note in which Miłosz is presented as a highly valued poet, the author of Rescue, involved in the literary underground during the war. All of these articles and essays are written in a style remote from his own. Editorial interventions are evident not only in their wording, but also in the syntax. While the English-language texts show a clear tendency toward dialogue, modulating tension through the use of examples and arguments, and coloring the argument with comparisons, phraseology, anecdotes, quotes, or aphorisms, the style of the Polish texts can be described, in the poet's own words, as ulizany - 'combed flat' or 'rendered squeaky clean.'

The constructional principle of the first two articles is based on a confrontation of the past with the present. The texts highlight the contrast between the scale of wartime destruction and the effort of the Poles to rebuild their country on the foundations of a new social order. The intention of both is to present the activity of the

166 Miłosz, Czesław: “Literature in Poland Today”, Poland of Today 1946, March, pp. 8-9.

167 Miłosz, Czesław: "Renaissance of the Polish Theatre”, Poland of Today 1946, April, pp. 5-6.

168 Miłosz, Czesław: "American Authors and Their Polish Public," Poland of Today 1946, October, pp. 3-4.

169 Miłosz, Czesław: "Intellectual Revival in Post-War Poland”, Poland of Today 1947, April pp. 7-8. 170 Miłosz, Czesław: "Literature in Poland”, Poland of Today 1948, April pp. 7-8 and 16. 
Polish resistance movement directed against the Nazi policy of denationalization. In the essay on literature, Miłosz raises the subject of mutual wartime assistance among writers and discusses personal losses in literary circles. He also characterizes postwar readership: that the publication of books increased despite shortages of paper, demand for new titles, discussions about new releases, and the activity of critics associated with the Polish Writers' Union. Miłosz addresses the path of advancement of rural and working youth wishing to achieve artistic or scientific success. Only in the second part of the article does he speak freely about the situation of literature after 1945. He emphasizes its serious, raw tone, its political and social commitment, the need for reckoning, which also means abandoning abstraction and vision in favor of the factual and the concrete:

The strain of tragedy and humor in real life had been too great for authors or the public to indulge in situations that are merely the product of imagination. Much rather there is a call in Poland for writers who would give a faithful picture of the stormy revolutions that shook Europe in the second quarter of our century: a difficult task indeed, demanding the stature of a Balzac or Tolstoy. The Polish novel shows a clear tendency to describe events that cover the span between 1939 and 1945, and in analyzing these phenomena, they go back to the original causes that led up to war and catastrophe. Hence, a great number of stories deal with the life and conditions in the years between the two world wars, with an emphasis on political trends (the growth in Europe of Nazi-totalitarian theories). ${ }^{171}$

Miłosz emphasizes the fact that contemporary Polish literature was still developing under European influences, especially French ones - in America such a rhetorical practice was well justified. He also explains the reasons for the heated nature of national artistic and philosophical discussions:

Europe had occasion to observe certain philosophical theories in the stage of their manifestation, when they took the form of gas chambers or manhunts for slaves. It can therefore be easily understood that expressions of opinion arouse passionate comments in Poland today. Even differences of opinion on such matters as theories on poetry or painting may give rise to discussions of fundamentally philosophical and ideological character, discussions that are being carried on with the fierceness of medieval disputes. ${ }^{172}$

In his opinion, the most important and most interesting disputes are those between Marxists and Catholics. Based on the course they take, Miłosz predicts the direction in which literature will develop, the place it will take in the public sphere, and its role in moral and psychological reconstruction:

171 Miłosz, Czesław: "Literature in Poland Today”, op. cit., p. 9. Cf. Matuszewski, Ryszard: "Polish Literature and the War," Poland of Today 1947, March, pp. 10-11; Matuszewski, Ryszard: "Polish PostWar Prose," Poland of Today 1947, December, pp. 3-4.

172 Miłosz, Czesław: "Literature in Poland Today", op. cit., p. 9. 
The devastation caused by National-Socialism in the psychology of Europe's nations is no less serious than the destruction of homes and factories. One of literature's outstanding tasks is to provide a cure for these disorders (...). ${ }^{173}$

Less probabilistic are Miłosz's conclusions in his article on post-war theater. He explains that, as the theater holds more significance to Poles than it does elsewhere, the first stages sprang up on the smoldering remains of Warsaw:

A desert of burnt-out buildings, mountains of ruble, twisted pieces of rusty iron, that is all that marks the surroundings of the "Teatr Polski" in Warsaw. One wonders where the public comes from, as there is nothing around but demolished and seemingly uninhabited areas. And yet the theatre is working and is always crowded to capacity, notwithstanding the difficult approach through streets where passage is so obstructed that no bus or streetcar communication could be established as yet.

This picture is characteristic of the overall situation in which the Polish theatre finds itself at the present moment. No sooner had the first waves of the 1944-1945 winter offensive surged inland than the first theatres opened up in their wake. The actors often played in street clothes and the unheated auditoriums were crowded with a ragged and often hungry public. People sat in their overcoats and followed with bated breath the words of the tragedy enacted on the stage. It was an appreciative public, longing for a classical repertoire. ${ }^{174}$

The author lists new theaters, theatrical companies, and schools, and explains the phenomenon of the development of performing arts with understanding. He emphasizes that Poles do not treat theater as entertainment - they place it between a religious rite and a national tribunal, assigning it the mission of continuing the Greek tradition. From this follows a characteristic feature of playwriting - Miłosz points to Dziady [Forefathers' Eve] by Adam Mickiewicz - grown out of a local pagan rite, to Shakespearean motifs found in plays written by Juliusz Słowacki, and to the mythical and Christian roots of the plays written by Stanisław Wyspiański. He points out that, despite cruel sanctions, theatrical life during the occupation did not freeze - it provided a counterweight to the Nazi tingeltangels and it became one of the most important forms of underground cultural life. Miłosz recalls the figure of the actor Igo Sym, shot for collaboration with the Nazis, and the punishment that fell on the whole theater environment because of this execution. He writes about the classical and romantic wartime repertoire, and the organization of the theater underground, emphasizing the fact that theater in Poland acts as a state institution, which allows it to maintain a high artistic level. The background of these remarks is an unspoken aversion to Broadway, a belief in the predominantly entertainment-centered character of American theater and the observation that, as other areas of culture, this one has

173 Ibidem, p. 9.

174 Miłosz, Czesław: "Renaissance of the Polish Theatre”, op. cit., p. 5. Cf. Ryszard, Matuszewski: “The Theatre in Post-War Poland,” Poland of Today 1947, June, pp. 10-13. 
also been harnessed here in the machinery of the market. ${ }^{175}$ Thus, the activity of Polish theater is an argument in favor of the political changes in his native part of Europe:

A theatre that can produce an artistically valuable piece, thereby rising in general esteem, will be granted by the Government or the Association more liberal funds to improve its stage equipment, decorations, etc. than a second-rate theatre which must run on smaller appropriations (the Polish public itself is poor). That is why theatres are glad to produce classics which offer the producer, the stage-manager and the actor a wide field for the display of their skills. ${ }^{176}$

Miłosz does not mention the shadow sides of the post-war theater: its politicization, the influence of censorship, a pyramid-like structure of management and financing. Rather, he speaks about the rapid pace of preparing premieres, an inundation of young acting and playwriting talents, the internationalization of the repertoire, and plans to set up rural stages - he mentions the establishment of an Art Institute in Kazimierz Dolny.

In his opinion, the development of theater is hampered by infrastructural deficiencies, the loss of many actors during the war, a shortage of men relative to women in drama schools, and the repertoire lagging far behind social changes. Regarding the latter issue, he poses the following question:

The increased participation in the cultural life of the nation by the lower strata of the population raises new problems. An often repeated question is: How can we create popular drama and at the same time maintain the highest artistic level? Moreover, due to the frequent changes in repertoire, the theatres are in constant need of new material. ${ }^{177}$

The last doubt reveals that Miłosz already formulates problems of development of culture under the influence of the new environment, in particular when we contrast his comments with Aleksander Janta-Połczyński’s critical remarks:

However, in view of the many stagings of plays by Russian writers in Poland, one wonders why, for example, Fantazy was not staged in Moscow at the same time? One does note, therefore, a one-sidedness to the cultural exchange between Russia and Poland, so that one can apply to it, in reverse, the saying concerning trade with our Eastern neighbor which has some currency today: we give them our coal, and in return they take away our sugar. ${ }^{178}$

175 In his articles for periodicals in Poland, Miłosz does not describe new theatrical phenomena in the US, such as off-stages, the establishment in 1947 of the Tony Awards, among whose first recipients were Ingrid Bergman, Arthur Miller and Elia Kazan, the emancipation movement in African-American theater or the New York stage successes of Tennessee Williams' plays.

176 Miłosz, Czesław: "Renaissance of the Polish Theatre", op. cit., p. 6.

177 Ibidem, p. 6.

178 Janta-Połczyński, Aleksander: Wracam z Polski [Returning from Poland], op. cit., p. 164. 
The essay titled "American Authors and their Polish Public" has an extensive autobiographical part. The poet mentions his childhood reading of novels by J. Fenimore Cooper, and Mark Twain, and his Grandmother Józefa Kunat's fascination with the poetry of Longfellow; he talks about the merits of modernists in popularizing the work of Edgar Allan Poe, and the popularity of the novels by Jack London after World War One.

It is only in the second part of the article that the author changes his perspective to a less personal one: he explains the interwar growth of interest in Upton Sinclair, Theodore Dreiser and John Dos Passos, explaining the reasons for Wilder's success on Polish stages. By suggesting which contemporary authors could gain success, he means success understood in American, that is, mental and economic terms. He recommends translation of Hemingway and Faulkner, who, in his opinion, would have a chance to be understood in Poland:

In Faulkner [a] Pole finds something of his own traditions. His presentations of the milieu of landed estates and his descriptions of the Civil War, which in its feats of desperate heroism resembles many an unfortunate Polish campaign, form a link between Faulkner and certain works in Polish literature. His descriptions of primitive nature as it is yielding ground to the march of civilization, is particularly near to our hearts (one of the classic pages in Polish literature is the description of a bear hunt). But above all, it is Faulkner's analysis of social problems which may help spread the fame of this outstanding author in a country that is profoundly interested in Balzac. ${ }^{179}$

Writing for American readers, Miłosz uses an important criterion for describing literature: he takes into account both high and popular circulation, emphasizing the interest Polish readers have in adventure fiction, sensational prose, crime-related stories, and romance. He ends the essay with a story about the phenomenon related to the novel Gone with the Wind, whose triumph far surpassed other translations of American fiction.

The structure of Miłosz's article, his choice of names, and the order in which he presents the translations allow the reader to look for parallels between his article and Sartre's essay on the French reception of American literature. ${ }^{180}$ They can, of course, be explained by analogies with European assimilation of cultural novelties from across the ocean; it is nevertheless also worth remembering the anti-Americanism shared by both Miłosz and Sartre, as was characteristic of intellectuals after the Second World War. ${ }^{181}$ While it is easy to predict that in France and in Poland in the first decades of the twentieth century the same authors and the same songs gained

179 Ibidem, p. 4.

180 This is about Jean-Paul Sartre's article “American Writers in French Eyes," The Atlantic Monthly 1946, August, pp. 114-118.

181 This issue is analyzed by Judt, Tony: Postwar. A History of Europe Since 1945, New York: The Penguin Press, 2006, pp. 220-221. 
audiences, this does not invalidate the significant similarities between the arguments made by Sartre and Miłosz, crowned with a half-jocular, semi-sarcastic commentary on the success of the novel by Margaret Mitchell. One of Miłosz's thoughts, which recurred later in his interpretation of short stories by Tadeusz Borowski, cannot be considered a borrowing - it is an observation on the tragic intermingling of life and literature:

The Polish boy owed a great deal of his education to his acquaintance with the adventures of the Wild West. I have no doubt that during the pitched battles the Partisans waged against the Germans, many youthful fighters found this an appropriate opportunity to emulate the heroes who were so expert at handling a lasso and who, with their pistols, hit the mark at 50 feet. Unfortunately this Wild West of theirs was infinitely more tragic, and millions of Polish mothers who today mourn the death of their sons are here to testify that the recent events had more in common with a Greek tragedy than with a thriller with a happy ending. ${ }^{182}$

The article "Intellectual Revival in Post-War Poland" was created on the margins of the deliberations of a UNESCO conference, where the program of cultural reconstruction of the West was elaborated. The article presents the progress made in reconstructing literary life in Poland through the development of state and private publishing houses and libraries, the initiative of making new translations and reissues of the classics of foreign literature. Miłosz emphasizes in it the country's openness to new Western art and the improving access to foreign magazines.

The article provides an opportunity to thank American institutions and organizations for their help thus far, and to encourage further support - the author mentions several times the needs of destroyed libraries and universities. In his discussion of the press market, he focuses on illustrated and literary magazines - he first talks about Przekrój and Szpilki, as if they were supposed to convey the freedom and optimism of the post-war press. ${ }^{183}$ He also emphasizes their cosmopolitan content:

The fact that Polish magazines contain a great deal of foreign material, must be undoubtedly booked to their credit. Cultural events and achievements in America, England, France and the USSR, are discussed in detail, and foreign poetry and prose appear in translations. After years of war, Poland is actually starved for contacts with other countries, and a number of Polish writers are traveling abroad in order to supply their public with articles and reports. ${ }^{184}$

182 Miłosz, Czesław: “American Authors and Their Polish Public,” op. cit., p. 4.

183 In émigré circles, the objectivity of Szpilki was treated rather skeptically, as can be gleaned from the poem "Odpowiedź" [A Reply] by Marian Hemar. In Hemar, Marian: Liryki, satyry, fraszki. [Poems, Satires, Epigrams] A collection of poems selected by Włada Majewska, London, 1990, pp. 103-106. Miłosz, too, was no doubt aware of both the profile of the magazine, and the attitudes to it in emigration.

184 Ibidem, p. 8. 
The country on the Vistula is presented as friendly to avant-garde playwrights. The development of academic potential is stimulated by educational exchange here a trip of physics and chemistry students to Denmark serves as a model example for cooperation with the West. Centers of musical culture are formed, whose task is to reach the widest possible audiences "in order to serve the country better as a whole, and to make musical instruction accessible to the broad masses." 185 Musical culture is becoming an issue that involves communities in joint projects, such as the centenary of Chopin's birth or the International Music Festival in London. The listing of achievements and innovations is concluded with a less optimistic reflection on the difficulties of artists and students of art colleges due to the shortage of materials, and with remarks on the difficult situation of filmmakers. Even there, however, the author can see positive changes: film chronicles are produced, foreign productions are more and more numerous, even though "[s]ince it is easiest of all to procure Russian films, there are more of these than any others. In the second place we find British, and then French films. American Pictures are in short supply because they are much too expensive." ${ }^{\text {"186 }}$ Miłosz's last article in Poland of Today is a propaganda synthesis of Poland's achievements in the short time following the country's liberation. It is meant to justify the necessity of systemic changes guaranteeing equal and unrestricted access to goods of culture, and optimum development conditions within the orbit of international influence.

The last article is focused on post-war literature. In the introduction, the author signals the difficulty of discussing it, resulting from Poland's history and the ties between poetry and drama and the national cause:

It is not surprising that Polish literature is little known abroad, for in Poland, the poetic and literary drama and poetry hold first place as literary events, while the novel, usually well received abroad, has not attained stability commercially, and pursues an erratic course. Besides, it is history that creates the literature of a nation. The history of Poland, due to her geographic position and social structure, has given her people many reasons for concern about her ultimate destiny. A literature of national prosecutors, national prophets, and national jesters, was the result. Sometimes, especially in poetic drama and in poetry, it evoked an unparalleled power of words and visions, but its essence was untranslatable. ${ }^{187}$

Miłosz puts Polish prose in the perspective of continental changes and argues that its current is a component of the pan-European process of development. He talks about Polish existentialism, starting with Stanisław Ignacy Witkiewicz, whom he presents as a theoretician of art and philosopher, and considers his concept of the "novel-sack" as a genuine manifestation of European reflection on prose. Mentioning Witkiewicz's

185 Ibidem, p. 8.

186 Ibidem, p. 8.

187 Miłosz, Czesław: "Literature in Poland”, A typescript of 7 pages. no date., op. cit., p. 1. 
suicide after the Soviet invasion of Poland, Miłosz emphasizes his keen awareness of the end of civilization, but presents it as the result of the outbreak of war: "Witkiewicz was a victim of the last war. Loathe to witness the victory of forces detestable to him, he committed suicide in 1939."

The second writer Miłosz discusses in the article is Witold Gombrowicz. His work, presented in an existentialist frame, is shown using the example of Ferdydurke. ${ }^{188}$ Miłosz draws attention to the themes of social satire in the fictional and non-fictional parts of the novel - citing Gulliver's Travels as its closest Anglo-Saxon equivalent. However, he also articulates these surprising words: "Gombrowicz now lives in South America, and, as far as I know, is not interested in writing."

The third author, Bruno Schulz, Miłosz first juxtaposes with Franz Kafka, and then with William Blake, due to the sheer expanse of their literary and illustratory visions. The example of Schulz, shot to death in the street of his hometown Drohobycz is used to visualize the fate of Jews in Nazi-occupied Poland. Interestingly, perhaps for practical reasons or for lack of a better common denominator understandable in the West, Miłosz lists the three authors as representatives of existentialism, long before this thought will become common in Polish literary studies. Miłosz contrasts this option with the pessimistic and realistic trends in prose. In the first one he places Jarosław Iwaszkiewicz with the story "Bitwa na równinie Sedgemoor" [Battle on the Plain of Sedgemoor]. The story inspires the poet to reflect on the insignificant role of man in history, the futility of effort and sacrifice. It is difficult to assess whether Miłosz talks about him as representative of Polish historiosophic reflection or as one closest to himself. In the realistic stream, Miłosz places the novel Blessed are the Meek [Polish title Bez oręża] by Zofia Kossak-Szczucka and Smoke over Birkenau, published in English in the Henry Holt \& Co Publishing House. He confronts here the concept of realism resulting from the experiences of the war with the realism of the pre-war novel and the postulated Marxist realism. He does not hesitate to voice this important assessment:

There are many discussions on realism in Poland today, and for a good reason, too. The average Pole of today is able to tell true stories, in comparison with which Kafka's fantasies look pale. Besides, to certain Marxist writers realism seems to be the truest concept of art. The trouble is that nobody knows what realism means. Is Proust, ask the critics, less realistic in his portrait of Charlus than Balzac? Do we have to return to Courbet in painting, and renounce all the history of modern art? It would be a step backward, not forward.

Poland does not afford a favorable climate for cultivating such extreme realism. That country has gone through the artistic revolutions of the twentieth century; and, what is no less important, most of the classical works of her literature are visionary and fantastic. A search for

188 A certain justification for putting Ferdydurke in the context of existentialism is the reception of Sartre's writing by American literary and cultural magazines. 
new forms which would fuse realistic and fantastic elements, is one of the common features of new Polish writings, while in painting abstract art is in favor. ${ }^{189}$

As examples of a successful fusion of realism and fantasy, the poet presents the novels Lake Constance by Stanisław Dygat and Sprzysiężenie [The Pact] by Stefan Kisielewski. The thought of the symbiosis of realism and imagination as one of the distinguishing features of Polish writing seems to be one of the first generalizations Miłosz formulates before becoming a literary historian in America. In the end, he devotes some space to poetry, pointing out the strong influences of French surrealism and affiliations with Eliot. Interestingly, Konstanty Ildefons Gałczyński is the only author Miłosz decides to introduce. Gałczyński in the talk is the creator of "Bal $\mathrm{u}$ Salomona” [Ball at Solomon's] and Zielona Gęś [The Green Goose Theater], a lover of Italian culture and pure-nonsense humor. How can this choice be justified? Did Miłosz intend to present the brighter side of post-war poetry, show its spectrum, prove its European roots? Following a recommendation from his superiors?

The articles in Poland of Today are not easy to comment on. First, the poet never mentioned them and was never asked about them - it is difficult to ask about texts one does not even realize exist. This creates a precedent in the space of Miłosz's literary output of which he himself was an indefatigable commentator. Post-war émigrés in the USA were certainly aware of the content of these articles, hence the divergent echoes of the "Miłosz case" among American Poles, a different assessment of his resounding "No" ${ }^{190}$ and a different overall outlook on the entire period of his diplomatic service. These articles cast new light on the "Miłosz case" and restate it. Aside from him, however, other well-known Polish authors cooperating with the bulletin also did not return to the period when they published articles in it. Among them were Aleksander Hertz, ${ }^{191}$ Ksawery Pruszyński, ${ }^{192}$ Jan Kott, ${ }^{193}$ Ryszard Matuszewski, ${ }^{194}$ Hanna Mortkowicz-Olczak, ${ }^{195}$ Jan Parandowski, ${ }^{196}$ Kazimierz Brandys, ${ }^{197}$

189 Miłosz, Czesław: “Literature in Poland”, Typescript ,7 pages. not dated, op. cit., p. 5.

190 “Nie” [No] - Miłosz’s famous article published in Kultura 1951, issue 5 (43), in which the poet explained his decition to emigrate; it was poorly received in Poland and in the circles of political independence émigrés in London.

191 Hertz, Aleksander: "How Poland Plans to Educate her Children," Poland of Today 1946, April, pp. 9-10.

192 Pruszyński, Ksawery: “Books, Books, Books,” Poland of Today 1946, May, pp. 1-2.

193 Kott, Jan: “Children’s Drawings,” Poland of Today 1947, January, pp. 8-9.

194 Matuszewski, Ryszard: "Zofia Nałkowska,” Poland of Today 1948, March, pp. 5-6.

195 Mortkowicz-Olczak, Hanna: "Polish Children Have a Press on Their Own,” Poland of Today 1947, March, pp. 6-7.

196 Parandowski, Jan: “The Museum of Shame and Crime," Poland of Today 1947, August, pp. 3-4 and 16.

197 Brandys, Kazimierz: “The Unconquered City. The Third Anniversary of The Warsaw Uprising," Poland of Today 1947, September, pp. 5 and 18. 
Michał Rusinek, ${ }^{198}$ Maria Dąbrowska, ${ }^{199}$ Józefa Wnukowa, ${ }^{200}$ Halina Wittlin, ${ }^{201}$ Irena Krzywicka, ${ }^{202}$ Stanisław Dygat, ${ }^{203}$ Stefan Kisielewski, ${ }^{204}$ and Mieczysław Jastrun. ${ }^{205}$ Zofia Nałkowska published here a fragment of the short story "Dwojra Zielona" and Dom nad łąkami [House in the Meadows], ${ }^{206}$ while Helena Boguszewska published "Bukiet bzu" [A Bunch of Lilacs]. ${ }^{207}$ In contrast to writers living in Poland and in emigration, Miłosz and Pruszyński wrote for the newsletter in an official capacity, as part of their work, which they had to face as diplomats; this no doubt affected the form of their articles. Secondly, the manuscripts of these texts have not survived (except for the essay "Literature in Poland", which also served as a text of the public lectures), ${ }^{208}$ and thus it is not known to what extent they were written independently. The English of the articles suggests that their language underwent modifications, but it remains a mystery whether there was any discussion regarding their final version, who took part in it, who approved them for publication, and what position was assumed by Miłosz.

On the other hand, the poet repeatedly expressed categorical disagreement with any interference in his literary works and articles published in Poland, beginning with the script of the film Robinson warszawski [Robinson Crusoe of Warsaw] written together with Jerzy Andrzejewski, and ending with his refusal to print the censored versions of his essays on literature. Thus we are left with numerous questions that can neither be rejected or verified - it is wise to look at this type of journalism as a manifestation of the post-war émigré fate of many writers. Witold Gombrowicz also prepared reports for Banco Polacco, although he did not sign them - while Miłosz lent his name to the bulletin of the institution with which he was bound in a "devilish pact."

198 Rusinek, Michał: “Theatre in Poland,” Poland of Today 1948, January, p. 4.

199 Dąbrowska, Maria: "Children of the Ghetto," Poland of Today 1947, March, p. 8.

200 Wnukowa, Józefa: "Sopot Institute of Fine Arts," Poland of Today 1948, February, pp. 10-12.

201 Wittlin, Halina: "Polish Post-War Stamps Series," Poland of Today 1948, July, pp. 10-11.

202 Krzywicka, Irena: "Idealists in Action," Poland of Today 1948, September, pp. 18-19.

203 Dygat, Stanisław: “The Philosopher Panteleon,” Poland of Today 1948, November, p. 12.

204 Kisielewski, Stefan: “Chopin,” Poland of Today 1949, October, p. 5.

205 Jastrun, Mieczysław: “Adam Mickiewicz. A Revolutionary Mind of Many Faces,” Poland of Today 1950, March, p. 12.

206 Nałkowska, Zofia: "Dwojra Zielona," Poland of Today 1947, December, pp. 8-9 and 16; "House in the Meadows," Poland of Today 1948, May, pp. 7-8;

207 Boguszewska, Hanna: “A Bunch of Lilacs," Poland of Today 1948, May, pp. 5-6.

208 The lecture in question is Miłosz, Czesław: "Literature in Poland", Typescript, 7 pages, no date, Beinecke Library, Box 123, Folder 1910. In the manuscript, the information on Stanisław Ignacy Witkiewicz's suicide in the wake of the Soviet invasion in 1939 was crossed out. It was preceded by an enigmatic remark that Witkacy took his life in protest against the victory of the forces that he hated. Also the remark on Gombrowicz's lack of interest in writing is crossed out. The manuscript shows signs of being read by an editor, whose comments are then further commented by Miłosz - there are suggestions in black ink, in a different handwriting, some of which have handwritten replies next to them. 


\title{
The English-Language Talks
}

One of the first and most frequently presented talks by Miłosz was devoted to the issue of Polish antisemitism. The poet writes from the position of a witness to the Holocaust, which is to make his position credible regarding the post-war situation of Jews. He begins with the statement that antisemitism is a pan-European phenomenon, however strong the tendency to attribute it to just one nation:

Because I lived in hell, I don't think it is proper to mince words. I think that the greatest danger for the world is a fear to name black what is black and white what is white. The problem of antisemitism in Europe is just an example of that fear and every nation tries to whiten its conscience, lest it be accused of a trace of moral complicity with Germans. ${ }^{209}$

Miłosz talks about Poland's unique situation on the European scale, in which the Nazis set up death camps for Jews from across the continent and punished with death those who dared help them. He discusses cases of people who helped Jews despite their personal dislike for them. He points out that the war united Poles and Jews against the common enemy only to some extent. He does not conceal the fact that pre-war antisemitism was strong in Poland. It seems that these fragments of the talk prepare the ground for Native Realm. They are an attempt to refute the accusation the diplomat struggled with overseas and that was also leveled at the communist government. Miłosz argues that post-war antisemitism is marginal, as only one and a half percent of the former 10-percent Jewish population survived and remained in the country. He claims that antisemitic attitudes are alien to intellectuals and politicians, and the government condemns them by imposing the death penalty for assaults on Jews. People of Jewish descent hold high positions in state administration, the army, and institutions of science and art. How does Miłosz explain the phenomenon of postwar antisemitism?

\begin{abstract}
Antisemitism is by no means encouraged and protected by the official political parties as it was in pre-war Poland. If it still exists, it is a remnant of the past and has no chance of remaining in the future. (...) You must realize that Europe as I said before, is not only a wasteland of demolished towns and villages, but it is morally destroyed. The recovery will be slow. The most important factor in the problem of antisemitism in Poland is political struggle. The Jews, as it happens, perish at the hands of armed gangs, are victims of a terror directed by fascist reactionary groups against the leftist parties. As you know, Jew baiting is and has always been the strongest weapon of the reaction. The groups, which before the war, promoted anti-Jewish actions and were opposed to all social reforms, are now very grudgingly accepting their loss of power.
\end{abstract}

209 Miłosz, Czesław: "I have lived through all the years..." Typescript no title or date, Beinecke Library, Box 156, Folder 2468, p. 1. Left-wing papers wrote extensively on American antisemitism, in particular The New Republic. 
They try to gain public support spreading the opinion that too many Jews are occupying high positions in the government and in the central committee of the political parties. They commit murders on Jews as well as on leaders of the democratic movement. ${ }^{210}$

This short passage contains several threads of thought in highly abbreviated form. The abbreviations, however, are not the only reason he departs from reality. The poet was aware that the problem he was trying to explain briefly was far more complex and less clear. Perhaps the choice of this line of argumentation, apart from propaganda reasons, stemmed from the conviction that it belongs to that kind of historical entanglements of Polishness, which are not easy to unravel even for Poles, and explaining them to foreigners is all the more difficult. ${ }^{211}$ As the poet confessed in a letter to Henryk Grynberg, in America explaining the fate of Jews under the occupation posed a formidable challenge as many of his interlocutors believed that round-ups in Warsaw, for instance, applied only to Jews.

It was not only the subject of the Holocaust that did not lend itself to be easily handled in the framework of a lecture - the very question of war in Europe caused similar problems, as Miłosz wrote in Inne abecadło [Further ABC’s]:

When I found myself in America right after the war, I could not tell anyone about what went on in Poland in 1939-1945. They did not believe. They believed that, of course, during each war the press wrote out the most horrible things about the enemy, but when the war would end, everything would turn out to be just propaganda. Pure evil? Would you really want us to believe in the existence of the devil? (Inne abecadto, [Further ABC's] 58-59).

\section{“Literatura w Polsce” [Literature in Poland]}

Another single-thread talk by Miłosz was the lecture "Literature in Poland". There was also a shorter version, ${ }^{212}$ a compilation of fragments from the earlier, longer text ${ }^{213}$ (which version is older can be determined thanks to the information on the date of publication of Smoke over Birkenau). In both texts, the poet appears as a historian and critic of literature for the public who lack elementary knowledge about his country.

\footnotetext{
210 Ibidem, p. 3.
}

211 Issues of the Holocaust, the situation of Jews and antisemitism in Poland were touched on in Poland of Today. See Galewicz, Jan: "Jews Find a New Life in Poland. Antisemitism - Weapon of the Reaction," Poland of Today 1946, April, pp. 3-4; Dr. Michael Szuldenfrei: "Rehabilitation of Polish Jews," Poland of Today 1946, April, pp. 5-6.

212 Miłosz, Czesław: “Literature in Poland”, Typescript, 7 pages, no date, Beinecke Library, Box 123, Folder 1910.

213 Miłosz, Czesław: "Literature in Poland”, Typescript, 12 pages, no date, Beinecke Library, Box 123, Folder 1910. 
This is a challenge and an opportunity at the same time. In the shortened version, Miłosz does not make any use of this, but in the more extensive version, he appears for the first time in the role of a creator of his own image of Polish culture. Interestingly, the image he outlines at the time, closest to his own experience and convictions, was to remain unchanged in its basic form and would become the basis for his later views.

The shorter (and later) version of the talk, with editorial additions and alterations, was presented as an article in Poland of Today. In the earlier version, also written in 1947, Miłosz problematizes the issue of Polish literature and provides a wider historical context for it. The introduction serves to consolidate two important assumptions: first, that Polish literature is European literature par excellence, and second, that its source is social change typical of the Old Continent - Miłosz emphasizes Poles' involvement in various national uprisings abroad, such as the Paris Commune, and the American War of Independence. The poet takes the opportunity afforded by giving a talk on literature to mention the traditions of Polish Golden Freedoms, religious tolerance, and Protestant movements in the sixteenth century, the age of Golden Liberty, liberum veto, the fall of the magnates and the rise of the intelligentsia, the influence of Catholicism and Latin culture on Polish national culture, the role of the Church and the Papacy in history, and the influence of France and Italy on Polish art. He emphasizes that the landscape of culture in Poland changed radically after the war, and one of the causes was the death of many artists and the most promising young talents. For the first time he reaches for the figure of Joseph Conrad, whose world-view helps Miłosz present the national character of the Poles - Miłosz juxtaposes it with the French character:

(...) Frenchmen do not like to die. Instead, they write good books about the underground and produce good pictures; and they have a sufficient number of heroes for their purposes. A Polish writer who glorifies patriotic duty is like a person who throws a spark into a keg of powder.

A French statesman said: 'The Pole is a man who, if you show him a precipice, jumps over it immediately.' He was right. The Polish writer should try to prevent such jumping., ${ }^{214}$

Important discussions on Conrad's writings were taking place in Poland and in the USA at the time. ${ }^{215}$ Giving an account of them in the lecture holds personal significance for Miłosz; it also provides the lecture with greater persuasive power. The speaker argues that in a country ruled by communists, free dialogue is possible with reference to the leading figures of literature, who wrote in exile, achieved international success and enriched the heritage of Western culture. Conrad's duality, a writer with a Polish mentality writing in English, as Miłosz presents him, is a prism through which he

214 Miłosz, Czesław: "Literature in Poland”, Typescript, 12 pages, no date, op. cit., p. 7.

215 They centered on the edition of The Portable Conrad, with an introduction and notes by Morton Dauwen Zabel, New York: Viking Press, 1947. 
wants to show the intellectual achievements of Poles; it is also a prism through which he looks at his own personal situation. He outlines a critical-literary typology here according to which the most important dispute over Polish culture is led by radical and moderate Marxists against right-wing and left-wing Catholics. For the first and only time in this talk, he uses a form of quasi-dialogue to synthetically include polarized opinions. This agonization of the discourse, frequent in his poetry and essays of the time, also proves to be an effective strategy for presenting contradictory views in the lecture. Where Marxists tend to emphasize that Conrad was a nobleman, loyal to a cause; he saw loyalty to a cause as good in and of itself, without questioning whether his sacrifice is useful to humankind, and it cannot be useful if it is for the sake of capitalism, which is, after all, doomed to fail. In contrast, Catholics will underscore Conrad's unshakable code of ethics, irreducible to utility, and they separate the social implications of sacrifice, regardless whether one wins or loses, from its moral value, as the judgment of one's deeds by history is always biased towards the winners, and it bears no influence on the moment when the decision is taken, when man is eye to eye to God. ${ }^{216}$

We are at the center of Miłosz's dilemma at the time, one that may be related to literature only distantly. The author of Rescue had been trying to settle this over the entire period of his diplomatic service, and probably even longer, as evidenced by the recollection quoted from $A$ Year of the Hunter. As one can see, the poet did not separate expository writing from his own situation and creative output. In the lecture, Miłosz considers the same issues as the author of Traktat moralny [Treatise on Morals and "Dziecię Europy" - and at a deeper level his literary work and diplomatic activity turn out to be coherent. This would also prove that Miłosz's official writing had a certain share in the reconstruction of his identity that took place in America. Unveiling a moral pain in a place where it was not visible (it is difficult to suspect that the American public understood the Polish background of his reflection on Conrad's ethics) was perhaps a mental safety valve in the situation of being forced to practice mimicry in diplomacy.

Miłosz also makes several comments in the lecture about post-war theater, emphasizing the popularity of Shakespeare on Polish stages. In the final part, devoted to poetry, alongside Gałczyński, he mentions Tadeusz Gajcy as a poet who was lost in the Warsaw Uprising. He seems to care little about extending the essay with more names or titles. It is also clear that with time and experience, Miłosz made various adjustments to his talks, when necessary limiting himself merely to providing information, and when possible, problematizing the issues, revealing mechanisms and complications of history, and outlining the political, social and mental background of contemporary works. By raising the bar ever higher for the listener, he argues that reflection on Polish culture is a prerequisite for understanding the

216 Miłosz, Czesław: "Literature in Poland”, Typescript, 12 pages, no date, op. cit., p. 8. 
experience of Europe in the past years and decades. The year 1947 is a breakthrough in this respect - perhaps at the moment of his promotion to secretary of the Embassy, he consciously adopts a very strong voice, setting the tone for the local discussion on Poland and Polishness, and forcing the recipient to make a considerable effort if he wishes to keep pace. A culmination of the Miłosz's public speaking activity is the publication "My subject is post-war literature in Europe...” translated into Polish and delivered at Columbia University in 1949. In both versions, Miłosz appears not only as a literary historian, but as a writer, sociologist and philosopher of culture, a political scientist, historian, and perhaps even a prophet.

\section{Lectures and Talks after 1947}

Miłosz's English-language lectures written after 1947 are seldom devoted to merely one issue. Several common themes recur, such as accounts of the European wartime experience, reflections on the possibilities of art, thoughts on the development of Western Civilization in the light of political decisions in America and - the most important question from the perspective of Miłosz's own development - how one can define the East and the West today.

In the lectures in English, the author often starts with the subject of war, because this issue is linked in a fundamental way with the issue of identity. He talks about the twilight of traditionally understood Europeanism. In the US he sees a discrepancy between the perception of Europe and its real image, unknown to Americans. He addresses this issue in an attempt to answer the question of how memory works in a situation where the world is changing at a pace that is increasingly more difficult to follow:

In one American literary review I found the following sentence: "We already know there is no escape from ourselves. The signature of ourselves is written over all our dreams like the criminal's fingerprints across his crime." (...)

I think it is true for people who, living in an unchangeable world, feel their own slow inner changes brought about by time. During all their lifetime they look through the window, seeing the same tree; years pass, nothing happens, and they are very busy with counting and recounting their past loves, past mistakes, and achievements. It is false for people who play their lives in a moving scene of a violent, impetuous world. They are so interested in what is going on outside and are compelled to so many quick decisions that their past mistakes and achievements lose any importance. They willingly admit the old wisdom of Catholic priests who believed that complacence in the subconscious darkness of the soul is a mortal danger. ${ }^{217}$

217 Miłosz, Czesław: “In one American literary review...” Typescript from 1947, no title, Beinecke Library, Box 125, Folder 1972, p. 1 and p. 3. 
The worn-out psychological remark in the review reflects the illusory belief that people can resist the influence of a dynamic reality, and that this manifests itself in supposedly constant and predictable reactions in new situations. Miłosz reminds the audience that such sentences, belonging to the psychological canon of pre-war discourse, could also be found in the Wilno literary press. However, the war falsified many of the early assumptions of the psychology of the individual, and altered the conditions of human development to such an extent that it posed entirely new questions for psychology. In the background of Miłosz's above remarks is one of his main beliefs about the role of the acceleration of history as the signum temporis of the 20th century. This conviction inspires him to reflect on the future human, shaped by the war and the consequences of a fast-paced and short-lived change. In this context, the central issue, related as it is to the problem of identity, is the question of memory. Existentialists, as the speaker claims, took away from the observation of change the conclusion about the decreasing importance of memory. Miłosz contrasts this statement with Marxist thought, which in its turn diminishes the role of individual memory:

On the other hand, Marxists ensure us that what happened has a meaning only if measured by the result of our actions. A heroic but useless death is nothing - neither good nor bad. The past for them is being continuously sacrificed for the future. Not individual memory, which is full of illusions, but the development of history can throw a light upon past events. ${ }^{218}$

Convictions of this sort, claims Miłosz, give rise to literature leaving less and less room for psychologizing. This still does not worry the poet much. He is, however, concerned about the direction in which people discarding the past and relinquishing memory will head, preoccupied as they are with the short-lived present.

\footnotetext{
You can say: They try to forget the years of war. Not only that - it is a mood of a constant revolt against one's own past, not only of the war, but also against the previous hour, the previous day. I have observed a febrile activity developed by people in ruined cities. America, which I had expected to be a country of calm, in comparison with the ant-like fretting of the human mass on the fallows of Europe. Obviously, there are, besides material reasons, some other reasons reaching further than the struggle for life. ${ }^{219}$
}

He is concerned about the direction in which literature will develop, when it is written as if the past had not existed. Miłosz presents his own understanding of memory which, burdened with the baggage of experience, governs thinking about the present and the future. Miłosz's European is someone who obsessively remembers. The poet places him between the poles of despair and the desire for purification. These poles

218 Ibidem, p. 2.

219 Ibidem, p. 2. 
are marked by Różewicz’s poems, "Lament” and "Oczyszczenie” [Cleansing], quoted in full in his translation. The role of memory in building one’s identity, as Miłosz understands it, goes beyond psychoanalytic definitions, but also cannot be reduced to an inventory of even the most broadly understood past. The past of which average Americans know little about regardless. Miłosz makes it very clear that the difference between an American and a European does not concern only the most dramatic difference in experience, but it depends on the style of thinking and action derived from individual and collective experience, sustained and motivated by memory. The poet uses here the traditional concept of history as life's teacher, wanting to prove that contemporary America and Europe are differentiated by their experience of war and its mental aftermath, which is the foundation of a new philosophy of life, morality, aesthetics, politics, etc. ${ }^{220}$ This gives rise to differences in practicing and understanding literature, and literature is the subject Miłosz wants to focus on the most:

There are some human experiences which are able to create in men a new philosophy of life. Such experiences, I dare say, were given to a great number of Europeans. It is difficult to define their new philosophy of life. One does not build a system of philosophy on such a thesis, as for instance, that it is good to live and to see one more spring, or that a loaf of bread is a treasure and woe to them who do not understand their happiness when eating their daily bread. ${ }^{221}$

Where Americans see no complications, Miłosz emphasizes their significance, sometimes taking recourse in simple rhetorical devices, such as quasi-introspection, as when he recalls going through the bullet-slashed streets of Warsaw one afternoon during the war, daydreaming of being able to go to the US and shout out all the atrocities on street corners, in all their horrendous details, to convince people such unimaginable crimes as manhunts and public executions are possible, and indeed that the very experience of war may in someone's mind take on a perfect permanence. Miłosz contrasts the vivid experience of war with the faded memory of it saying: “(...) now, when I try to remember and to tell, I cannot. I don't remember. Only a rough draft of a dream is left, dim and lacking color. I don't remember, or perhaps I don't want to remember."222

220 Marta Piwińska comments on this as follows: "The most important message that our culture may present to the West is of our historical experience, which is most difficult to understand. After all, what is the value of all these bad experiences - the partitions, the Second World War under the General Government, which looked very different from that in Paris, the passage through Stalinism? Both of them [Mickiewicz and Miłosz - E. K.] do not mean to obtain moral and political support on the basis of a history of martyrology. They tell their stories mostly for the West, to teach and to warn," op. cit., p. 87.

221 Miłosz, Czesław: “In one American literary review...”, op. cit., p. 3.

222 Ibidem, p. 2. 
In his English-language lectures, Miłosz provides many details of daily life under the occupation, despite his rhetorical stipulations that he does not remember them. He also does not avoid comments on the responsibility of the Allies for the fate of Poles:

In the summer of 1942, a big transport of Greek turtles was stolen in Warsaw. Its destination was the Eastern front for the German Army in Russia. The merchants would sell them in the streets, and masses of slow moving reptiles crawled on the pavements. The people of Warsaw called them "the vanguard of the American invasions." It was a cruel joke, too, because the people who were joking knew well the price in human lives which the occupied countries, and especially Poland, were paying for every month of the delay. ${ }^{223}$

Not only in his poetry, but also in the talks addressed to Americans, Miłosz complains about the problem of form. The American listener makes him realize that in time everyone would learn about the history of war without being able to refer to experience. In the record of this thought for the first time appears the metaphor of an avalanche, which made one of the lines of Traktat moralny [Treatise on Morals] an aphorism, in which Miłosz says that in Europe the memory of war will fade and die away in a matter of several years, but the experience of it will continue to exert unpredictable influences, much like a stone starting an avalanche down a slope.

Seeking a way to talk about the war and its long-term consequences, Miłosz feels more and more clearly the lack of a community of experience, which precludes agreement on a more abstract ground. In addition, aware of the national disputes over the realism of the literature under occupation, he shares his doubts:

There is no lack of heroic stories and novels in Poland. It is an outburst of long stifled passions during the war all printing in Polish was forbidden; only underground printing presses worked. Incredible stories of guerrilla fighting, prisons, escapes, concentration camps fill the pages of books and periodicals. The tragedy of Polish Jews impressed writers especially strongly.

All that is a realistic literature. Readers know the subject by heart, and they expect a good knowledge of details from a writer. Sometimes they ironically ask an author whether he has ever had an automatic gun in his hand, which is, of course, a deadly kind of literary criticism.

Zofia Kossak, a Catholic novelist, whose novel, Blessed are the Meek, was a bestseller in America a few years ago, has spent a certain amount of her time in one of the worst German concentration camps - that of Oświęcim (Auschwitz). She recently published a book on what she had seen there and was immediately attacked by former inmates of that camp for "not presenting the whole truth." The attacks were right to some extent, because a book on the same subject, Smoke over Birkenau, by Szmaglewska, a debutante, seems to be more accurate (the translation will be published in the fall in this country).

There are many discussions on realism in Poland, and for a good reason. An average Pole of today is able to tell true stories, in comparison with which Kafka's fantasies look pale.224

223 Ibidem, pp. 5-6.

224 Miłosz, Czesław: “Literature in Poland”, Typescript, 12 pages., op. cit., p. 10. 
Miłosz problematizes here the issue of occupation literature and tries to explain the sources of its specific form. This is the first time that he discusses irony as the hallmark of Polish creativity. He lists Fielding, Defoe, and Swift as icons of ironic literature in a sense close to his own. These authors - with the exception of Defoe, whose novels became the subject of a wartime essay - grew closer to Miłosz after he came to the USA. In the talk, the poet reveals the books he is currently reading, but their choice is a partial continuation of his pursuits under the occupation. He explains further the sources of the Polish authors' propensity for absurdity, black humor, and grotesque:

One of the most important factors of equilibrium and the best remedy against hysteria is humor. To tell the truth, the sense of humor developed during the war was cruel and cynical. The apparent cynicism, however, had an inner dignity and respect for human values. It was a sense of tragedy, and every witty expression could be classified in a category where no clear limits exist between the laughter of humans and the anger of gods. ${ }^{225}$

The war, as he argues, revived the importance of the literature of distance, which emphasizes the repetitive nature of fate, and typicality of behaviors. Reality, which blurred social and personal differences, gave precedence to those instincts and traits that guaranteed survival, and eluded psychologizing descriptions in favor of a reporting-based or more parable-like approach. Somewhat in reference to the occupation essays, Miłosz's talk on literature delivered at Columbia University on April 18, 1949, intimates that one of the few artists who did not lose value during the war was the author of The Human Comedy:

What fascinated us in Balzac is the ability of his characters to assume new incarnations. As my listeners will recall, Balzac's characters appear on the surface, sink and reappear in new roles, with a completely changed social position, dress, type of smile and a variety of reactions. ${ }^{226}$

Miłosz creates a typological portrait of a European artist, reader, and theatrical spectator formed by the war - a trained eye will find in it the outline of the author himself:

It would be very interesting to examine the literary taste of that poet as representative of a certain generation. I guess that he would like very few literary works from the first half of the twentieth century. He would probably be opposed to the so-called "roman noir" in France. It means the novel exploring desperately the abyss of the human soul. He would look critically, too, at the naturalistic violence of certain novels. Probably his favorite authors would be Rabelais, Defoe,

225 Miłosz, Czesław: "In one American literary review...”, op. cit., p. 5.

226 Miłosz, Czesław: “Odczyt o literaturze wygłoszony na Columbia University 18 IV 1949 r.” [My subject is post-war literature in Europe...] Typescript, no title or date, Beinecke Library, Box 125, Folder 1973. It is not known when and how many times the talk was delivered in English. 
Fielding, Swift, and Balzac, all of whom are eager to know as well the song of the nightingales as the life of human society; and, what is important, all of whom are very angry, but never hysterical. ${ }^{227}$

This new type of reader and viewer sets new tasks for of the author, ones that Miłosz jointly calls ethics:

After purely psychological interests have been reduced, an invasion of new elements begins. What are these new elements? First of all, ethics. I am afraid that in a few years the literature of many European countries will be a kind of big treatise on morals, and one can foresee the appearance of a new Prince of a modern Machiavelli. If I say "ethics," I do not have in mind the ethics of family life. A poor love story has no chances, and with regret I dismiss the beautiful female demons, whose charms I fully appreciate. They used their lipstick during the war; they carried shotguns when making up their faces; and those who survived continue to be impoverished demons. The writers pay very little attention to them. The ethics of the new literature are the ethics of ruling and being ruled, the ethics of war and of a difficult peace.

I am aware of a danger which threatens the writers when they become involved too much in the ethics of collective movements. I hope, however, that the old humanistic tradition of Europe will be able to reduce our errors. I do not believe that a man who reads Rabelais could be a fanatic. 228

Reflecting on the directions and possibilities of literary development after the war, the speaker recalls Tolstoy's views. He considers them not so much because of his listener, but rather for personal reasons. In the USA, the poet found himself in the pincers of contradictory views on the future of art, between Tadeusz Różewicz's pessimism, Joseph Conrad's ethics, the Marxists' historic determinism, Balzac's irony and Tolstoy's condemnation of art, bearing in mind Maritain's personalism, Eliot's diagnosis of the civilization, and his own conclusions, drawn before and during the war. In the position of a regime official in exile, without his own audience and with no hope for a new one, his doubts seem to intensify. From the difference between the experiences that shaped divergent philosophies of life in Europe and America, the poet derives still other questions: what are the East and West at present and what may post-war Western Civilization become?

I think that Western Civilization is something real. But, just as many things are real as long as we do not try to define and classify them, Western Civilization also seems to lose all reality when we divide the phenomena into two kinds: one of the Western, and another not Western. ${ }^{229}$

Miłosz asks rhetorically which country is supposed to be the border of Western Civilization, and he argues that such a border has never existed in history:

227 Miłosz, Czesław: “In one American literary review...”, op. cit., p. 5.

228 Ibidem, p. 7.

229 Ibidem, p. 7. 
Ancient Greece and Rome. But Jesus brought a teaching which was rather hostile to the Greek and Roman way of life. His message could be easily dismissed as un-Greek and un-Roman. Medieval Italy? But one of the greatest poems of Europe, The Divine Comedy of Dante was created not only as a result of the influence of Latin poetry, but also as a result of some literary ideas taken from Arabic poets, who were infidels and decidedly Eastern. The history of medieval philosophy shows continuous Arabic influences, and one should remember what chasm existed at that time between the Christian and the non-Christian world. It would be easy to quote many examples. It would not be an exaggeration if I say: Every real civilization is universal and open to all kinds of new ideas. The critical moment arrives when it becomes self-conscious to such an extent that it is afraid to lose its ideal purity. We have then the case of Julian the Apostate who did not want to accept Christianity and fought in the name of old gods - not because he believed in them, but because they were Western. ${ }^{230}$

Miłosz's reflection had at least two motivations. The first resulted from his observation of the foreign policy of the US. The second derived from his reading of global history and works of literature from ever widening linguistic and cultural circles. The year 1947, from which the talk comes, saw the beginning of the Cold War. When in his Fulton speech Prime Minister Churchill used the term iron curtain, President Truman announced his doctrine, and the Congress passed a law on immigration quotas discriminating against Eastern Europeans, it was evident that the definition of Western Civilization was based on the narrowly understood political criterion. The diplomat therefore presents the position of a representative of the world behind the Iron Curtain, to demonstrate the myopia of such reasoning:

We in Europe observe with anxiety how the words "Western Civilization” are being transformed into a political weapon. I think there are many much cheaper words which could be used for such a purpose. Whoever draws a line through the heart of Europe and says: On this side is West, on that side is East, can be accused of making from the common inheritance of mankind a ball for the game of politics.

Let us suppose that such a line is drawn and that Poland or Czechoslovakia do not belong to Western Civilization. Let us state, however, that what is going on in Poland and Czechoslovakia is much more similar to what is going on in France, than what is going in the United States. So, perhaps we should be obliged to move our line and make the Atlantic a frontier between the two civilizations. Now Descartes is already an Eastern philosopher. ${ }^{231}$

Miłosz's hypothesis, even though it might have seemed to be an interesting thought experiment, was not speculative for the poet himself. Miłosz is convinced that if the current boundary of civilization should run somewhere, it was marked out in the hell of wartime experience that integrates Europeans opposite Americans who did not live through it:

230 Ibidem, pp. 7-8.

231 Ibidem, p. 8. A different perspective on the division into the East and West is taken by Judt, Tony: Postwar, op. cit., pp. 100-128. 
Speaking of war experience, I had an obvious aim: to look for elements common to the people of all the countries which suffered during the war. Hitler's ambition was to unify Europe in serfdom. He succeeded not in the way he planned, but nevertheless he succeeded. When I meet a Frenchman or a Dutchman, I ask him about the manhunts in his country during the war, or about their black market, or about their underground press, and we [understand] each other perfectly. If I try to communicate to an American a bit of our irony or of our childish joy typical to the men who are glad to see one more spring, we stammer, and I confess that we are bores. ${ }^{232}$

The poet was a witness to the breakup of the continuity of civilization in Europe - he will say it even more clearly in his lecture on literature at Columbia. Burying the old Europe and the necessity to build a new one seem to him to be urgent tasks as they are insurmountable. For this reason, he considers belief in the civilizational unity of the Old and New World a manifestation of a certain sentimentality, less and less justifiable in post-war reality, whereas attempts to create a new map of the West based on political calculations are to him more harmful nonsense. ${ }^{233}$ In these views he was not isolated - discussions in a similar spirit took place on the pages of the American press; one may also ask about the influence of Eliot's Notes on the Definition of Culture on Miłosz's thinking. His own comments on civilizational fluidity have yet another value - in his ironic assessment of the political attempts to build a new rampart, he questions the possibility of creating a world on the principles of the center and the provinces. Does the then dialectician, but also reader of Faulkner, have a sense of the emergence of a polycentric civilization?

\section{The Chicago Lecture}

The archives show that at least once the lecturer drew different conclusions from the experience of war. He talks about them in his lecture of December 19, 1948 at the Art Institute of Chicago, which accompanied the exhibition brought from Poland by Wanda Telakowska. Does his bright tone result from the presence of a guest from home, or from predictions that the audience will include Poles and representatives of the local Consulate, or is it a result becoming acclimatized to the realities of life

232 Miłosz, Czesław: "In one American literary review...", op. cit., p. 8.

233 It is interesting what Miłosz says about it then in the "Notebook:" "Bednarczuk [Jerzy Putrament] is proposing writers to finish looking to the West. Where does he see this West? What is it supposed to be? The cheese trimmings: France, Italy, Switzerland - a few small countries in transition and of secondary import? America is not the West; no one believes it. Unless one accepts that the West is capitalism, which American journalists do 10,000 times a day. They print reproductions of Italian Renaissance painters in their magazines, trying to convince their readers that America is the rightful heiress of Raphael and Tintoretto, which is obviously untrue. The Middle Ages, the Renaissance and the Baroque had a completely defined territorial range in Europe, these layers were deposited in folklore, even in folk painting." In Miłosz, Czesław: "Notatnik" [The Notebook], Nowiny Literackie 1948 , issue 15, p. 2. 
in the USA? Utopian visions of the development of Poland and humanity diverge significantly from previous statements about the impasse of Western Civilization. The reason for this seems to run deeper and it was, I believe, revealed in the essay "Mickiewicz and Modern Poetry", published in December 1948; the Chicago lecture and the article written at the same time share a common patron, and so it can be assumed that at least a part of their assumptions and points also converge. In the essay, Miłosz says that the sense of equilibrium permeating Mickiewicz's works would suggest that it is periods of transition that are richest in literary terms, as they are periods when certain modes of feeling and reasoning are taken away but remain as a basis for a new effort.

However risky this statement may be, around 1948 Miłosz himself was similarly at the end of a transition period in which some processes and transformations had been completed, and new intuitions had become clear. This situation is radically changed in 1949, particularly after the poet's return from Poland, but 1948 seems the most fruitful in his entire first American period. The figure around which several threads of reflection in the talk are spun is of course Adam Mickiewicz. Miłosz describes him as he did in the 1930s, both in his journalism and in correspondence. ${ }^{234}$ Here, too, Mickiewicz embodies a harmonious convergence of poetic talent and sociopolitical activity, a unity of word and deed. Mickiewicz in the talk becomes at the same time the archetypical Polish poet, to whom successive generations entering the literary stage must relate. Miłosz talks about resurrecting the paradigm of independence literature during the war, about a renewal of Polish underground traditions, about the artistic and educational activities of the underground, about the hunger for poetry in the realities of poverty under occupation, and the illegal, perilous ways of its dissemination. Nowhere else does he speak with such sympathy and appreciation for the poets of the Warsaw Uprising. It is worth bearing in mind that Gajcy, who was killed in the Warsaw Uprising, is for him still their most interesting representative. ${ }^{235}$

Miłosz does not use the term "Romanticism" anywhere. He clearly separates the romantic attitude from literary form. The former he discusses in the lecture although without the use of the word "romantic" - in his accounts of the activities of the Polish Underground under occupation. He explains the complexities of this terminology in Poland in the essay, while in the talk he avoids oversimplified classifications. Remarks in the essay and the lecture coincide with their treatment of the style of Mickiewicz's poetry and his attitude to tradition. In both places Miłosz

234 See Miłosz, Czesław: “Mickiewicz. (Na marginesie wielkiego cyklu Polskiego Radia)” [Mickiewicz. (On the Margins of the Great Polish Radio Series)], Antena 1939, issue 23, p. 4. A reprinting of Przygody mtodego umyshu. Publicystyka i proza 1931-1939 [Adventures of a Young Mind. Journalism and Prose 1931-1939]. Collected and edited by Agnieszka Stawiarska, Krakow, 2003, pp. 285-290.

235 Miłosz, Czesław: “Let us avoid generalities...” Typescript, no title or date, Beinecke Library, Box 156, Folder 2467, pp. 3-4. 
emphasizes Mickiewicz's simplicity of style - he defines it in Eliot's terms, as the ability to use language. Likewise, he characterizes Mickiewicz's fusion of tradition and modernity - although it is less apparent in the talk, Mickiewicz's portrait of 1948 is put in an Eliotesque frame. Speaking about Mickiewicz, Miłosz explores personal questions about the relation between poetry's autonomy and its social engagement. It is no coincidence that Miłosz portrays the bard as a young exile to Russia, editor of La Tribune des Peuples [The People's Tribune], who granted his support to the American aspirations to freedom, a creator of the legions, and above all a lecturer of Slavic literatures at the Collège de France, who lost his prestigious post as a result of spreading radical political views and philosophical ideas. Let us not forget that Miłosz himself at the time considered the possibility of joining the Hutterites. His Mickiewicz is a visionary, prophet, tribune, believer in pan-Europeanism built on the foundations of Christianity - a prime example of a Polish poet who also grows into the sort of symbolic image of a poet in the sense of what Whitman means in America. Miłosz does not hesitate to build a bold parallel between the bard and the visionary poet; moreover, he makes this juxtaposition the plane of a kind of brotherhood, the basis for seeking unity - seeking a covenant. Most interesting here seems to be the reinterpretation of Mickiewicz's biography, so that he could be his patron at that time. Mickiewicz - the ardent poet of the suprapartisan left, the Christian poet, the poet of the future, the Polish poet, teacher, social activist, political activist, leader, and organizer legitimizes the employment of a secretary of the Embassy in his secret service of the invisible legion. As Ryszard Nycz writes about the author of Rescue:

\begin{abstract}
Miłosz aims consciously and consistently in all of its manifestations of his work, including (and perhaps especially, because here is where it is most difficult) in his poetry, at sustaining and developing - right at the time of modernity, in the period of the avant-garde and post-avantgarde - a conception of practicing and understanding literature as a public matter, as the art of articulating public issues, and as a medium and avenue for the organization of intellectual life in the public sphere (...) Seen from this perspective, the "more capacious form” of Miłosz's designs is essentially a project of conceiving poetry as the koine of the twentieth-century experience. It is the development of a poetic discourse that connects literary genres, the lyric, the epic, the dramatic, the reflexive, as well as distinct sociolects and discursive registers. It is also poetry that becomes not a passive carrier, but an active bearer of the "spirit of the times," lending shape and crucial meaning to the problems of the shared and individual experience of man. ${ }^{236}$
\end{abstract}

Miłosz adorns his remarks about the inalienable role of poetry in society with a propaganda account of the successes of the post-war reconstruction of Poland - he

236 Nycz, Ryszard: Czesław Mitosz: The Twentieth-Century Poet in Public Space. Translated by Jennifer Croft. In Czesław Mitosz, Multiple Worlds, Game of Forms. Published under the direction of Stanisław Latek, Krakow, 2011, pp. 24-25. 
maintains that poetic energy, and the desire to revive humanity and create a new world flow from a single source. He cleverly uses reports from press correspondents of the Manchester Guardian and The Washington Post, who commented with some admiration the pace of reconstruction in the war-ruined country. However, the main topic of the lecture goes deeper and coincides with reflection on the possibilities of shaping reality with the help of verse. In Miłosz's own words:

I do not feel guilty of disrupting the continuity of my speech by talking about economic reconstruction of my country. Poetry is life; it is as I said, the very essence of life activity, so industrial activity is life too, and it is absurd to separate those things. The same daring and bold spirit which created the great Polish national poetry and led young poets in the fight against the invaders, explains the successes of Poland's reconstruction. ${ }^{237}$

In this talk, for the first time Miłosz answers in the affirmative the question about the salvational dimension of poetry - about its significance in repairing people and the world. A point of departure for the talk is the issue of happiness, in which:

[p]oetry is nothing else but a sort of revolt against the unhappiness of man. (...) Poetry is more than an occupation, it is activity at its purest, the essence of activity, since a true poet criticizes the world in which he lives for the sake of a better world of the future. ${ }^{238}$

\section{The Lecture at Columbia}

As I mentioned, the Chicago lecture seems exceptional in comparison to all the other American lectures. A lecture that gathers all the previously spoken thoughts, doubts and opinions, a crowning of the public speaking efforts of the diplomat, is the one delivered on 18 April 1949 at the University of Columbia. It is a translation of an earlier talk written in English - it is not known where and for which audience it was presented. It can be regarded as the crowning of Miłosz's lecturing activity, if only for the reason that he says the same to the Polish and English-speaking audiences, without differentiating the subject, or the manner of its communication, as if at the end of his stay in America both communicative situations finally became one. Phrased differently, after several years of living overseas, Miłosz's identity is refined, becoming coherent with all partners with whom he needs to negotiate it. This is the moment when everyone can be told the same thing. The poet knows the audience he will speak to - these are lecturers and students in the Department of Polish Literature, some

237 Miłosz, Czesław: “Let us avoid generalities...” Typescript, no title or date, Beinecke Library, Box 156, Folder 2467, pp. 4-5.

238 Ibidem, p. 2. 
of whom he knows in person. He knows what he wants to say and why - although the title of the lecture suggests a literary subject matter, it is a personal, sometimes very intimate confession of a writer forced to re-evaluate many of his beliefs, one who reached an awareness allowing him to make use of his experience. On that day Manfred Kridl wrote the following:

\begin{abstract}
At the second meeting of the "Koło Polonistów" [Polish Circle] Mr. Czesław Miłosz, noted Polish poet, gave a lecture about "Post-war Polish Literature."

Mr. Miłosz characterized the spiritual and moral condition of post-war writers in Europe in general, their new tasks, their attitude toward the recent past and their search for new forms of expression.

The situation in Poland is analogous, generally speaking, although there are differences caused by the devastating war and basic social changes after the war.

The lecture was attended by approximately 25 persons. A lively discussion followed the lecture. ${ }^{239}$
\end{abstract}

The speaker refrains from listing names and titles, and cataloging phenomena; he forsakes the role of a historian or critic. In other words, if Miłosz devotes a lecture to literary issues, he constantly emphasizes the subjectivity and dynamism of his account. Speaking of literature, he talks about himself, and in turn, he objectivizes this confession and derives it from his own experiences the situation of a European author in the first half of the twentieth century. The reading is governed by the rule of pendulum-like oscillation, going from the personal to the literary and back again, and from the personal to the typical and back. The center of reflection is the "I" subjected to the variability of historical experience, redefining oneself, one's duties and possibilities of acting under its influence. Starting from the definition of evolutionary change, as in all the previous lectures, Miłosz talks about war as world-shattering formational experience, incomparable to his earlier experiences. After a few years of living in the USA, he finds a new way to talk about it - he compares it to natural disasters. ${ }^{240}$

The breakdown of identity - a fact about unpredictable, long-term consequences - Is the right prism through which, in his opinion, one should look at Europe. Miłosz appears here as a castaway who, unlike Daniel Defoe's protagonist, has no hope of resurrecting the old world with its people.

Even though the author alternately speaks in the first and third person, there is no doubt who he is talking about - a former critic of avant-garde formalism, author of

239 Kridl, Manfred, "Polish Circle (Koło Polonistów), Columbia University, Dept. of Slavic Languages." Manfred Kridl Collection, Columbia Rare Book and Manuscript Library, Box 17, Subject File: Polish Circle (2) At Columbia.

240 See: Czesław Miłosz, “My subject is post-war literature...," Beinecke Library, Box 125, Folder 1973, p. 3. Through this analogy Miłosz refers to the way in which Americans described the experience of the Great Depression. 
the "Piosenka o porcelanie" [Song on Porcelain], a translator of T.S. Eliot, a reader of Tadeusz Różewicz. He is the Robinson Crusoe of Warsaw, walking through the ruins of the city with no illusions that the culture of Europe can preserve its continuity:

(...) there is a sharp dividing line between pre-war Europe and the Europe of today. In spite of all the illusions many people cherish in this country, nothing can be patched up and forgotten. There is no such thing as a "return to normalcy" (...)

In the spring of 1945, I revisited, after a several months absence, my home in Warsaw. The house had been split by an artillery shell. A page by André Gide was flying on in the ironic wind. There were some trampled covers of other books - the treasure of a pre-war writer: Rimbaud, French surrealists, Kafka, Proust. They looked rather silly against the background of ruins. ${ }^{241}$

In these observations, Miłosz could be close to Tolstoy's condemnation of art, to which he had alluded in his previous lectures. On the other hand, he is accompanied by the following thought:

The basic question is: what values remain? No one can live forever amidst the rubble of his destroyed loyalties and convictions. Even the smallest bit of ground cleared of debris is better than a vast space strewn with bricks and haunted by ghosts. Those who succeed in clearing a little bit of their own are happier, I feel, than those who have never been confronted with the necessity of doing such a work..$^{242}$

The paradoxical advantage of this situation is, in his opinion, the awareness of the relativity and changeability of the world reorganized from scratch. Persisting in the reality that is undergoing elusive changes creates a dangerous faith in its universality and durability. This is the charge he brings against Americans:

Perhaps it is good for man to remember that the world in which he lives has been made by his own hands. Not only the houses in which he lives, the clothes he wears, but mental and moral atmosphere which surrounds him is a product of his own will, or lack of will Deprived of the electrical shock which comes from the sudden events of history, he takes too often the order of things established in his little town for a pattern of the universe. What is typical for a moment in the development of mankind appears, for him, to be an immovable law. There is no better example of such an attitude than Spoon River Anthology of Edgar Lee Masters, that tragedy of a provincial microcosm. Many other names of American literature could be mentioned in this place. Here is probably the source of American selfthoughtness on one hand, and the naturalistic and biological tendencies of American literature on the other. ${ }^{243}$

One can debate whether Miłosz's judgments are fair. The above passage, however, does explain many of his idiosyncrasies of the time, concealed in his claims that the

241 Ibidem, p. 4 and 7.

242 Ibidem, p. 4-5.

243 Ibidem, p. 5. 
American city is reminiscent of a museum of technology, that it is a distorted imitation of the European original, that because of isolationism, America is like a flower folding back its petals, that it resembles the world on the first day after creation. Overseas, the poet constantly stumbles over the relics and reduced survival forms of a reality that is considered very much alive here:

To my astonishment, I noticed, after coming to America, that writers and publishers have been busy with translating, commenting on and publishing Gide, Kafka and surrealists, as if nothing had happened. Those phantoms of my youth, which symbolized for me the past, flourished in a mental climate which was a strange mixture of the early 20 century refinement and the American Revolution. As for rational behavior, I had to say farewell to it, and very soon, while still in Poland. Nevertheless, my journey to a country untouched by war was no less exciting that of Gulliver to the country of the Houyhnhnms. I assure you that it is the greatest fun a man can have. I felt I had that god-like eye which can, as you will remember, see through the vanity and emptiness of human desires. ${ }^{244}$

Therefore, in the Columbia lecture the poet mentions two types of despair: of necessary transformation and of persistence - in his opinion the former is reflected well in the situation of Robinson, the latter was described ironically and with no illusions by T.S. Eliot on the eve of the war. Is this said by a believer in the Spirit of History? Explaining the selected fragment of The Waste Land, the author uses terms from a very different vocabulary:

The stony rubbish of our civilization can be interpreted (...) in terms of a mystical night of soul. But there is a place for a suspicion that those who limit themselves to sitting in a dark room and expecting a sudden change through grace, hope to be reborn without the pain of dying. Like the people who are unable to imagine immortality without their glasses, their radio-set and their liquor-store, they wish to get something without giving anything away. ${ }^{245}$

Who would die here? Robinson of Warsaw. Who would be reborn? At this point in the lecture it becomes evident that it was created at the end of Miłosz's diplomatic service. The speaker is able to look at his situation from a distance - to objectify it and put it in a paradigmatic form. He puts his wartime experience and his American experience in a broader perspective, which allows him to believe that the process of death and rebirth presented here was already largely behind him.

This argument allows Miłosz to deal with the literary programs debated in America and Europe. Once again he recalls his criticism of psychological literature, rejects existentialism as a new form of dreamy idealism, he confronts Tolstoy's view of the immorality of art, and finally explains the phenomenon of the popularity of Marxism:

244 Ibidem, p. 10.

245 Ibidem, p. 8. 
The Marxist theory of literature is indebted, I feel, as much to Marx as to Tolstoy. That theory is winning more and more followers in Poland. It treats literature as a politico-moral weapon and is concerned more with aims, than with means, more with content than with form, more with actuality than with everlasting beauty. Or to put it in the other way, it maintains that means, form and beauty are lifted and perfected if the content is good.

One should remember that the experience of change which I tried to touch upon, preceded the successes of the Marxist theory in Europe. The ground had been explored in all the directions and all the possibilities exhausted. The advent of the Nazi empire cast a shadow of complicity upon many a school of pure poetry and many a philosophical doctrine. The liberal faith was dying out and those liberals who survived can hardly be counted among the liberals, since they saw the death of millions and millions of innocent human beings and anger does not go together very well with liberalism. So the field was prepared. That explains, too, the weakness of the antiMarxist opposition to literature. The opposition inscribe on their banner fine-sounding words, dear to everybody who is not a beast. The only trouble is that those words are just words, nothing more and we are fed up with meaningless words. ${ }^{246}$

It is difficult to imagine that the superiors of a poet who proclaims such views publicly could continue to have confidence in him. It is clear that Miłosz had made decisions regarding his future and he put the ability to express himself freely over the Embassy's approval. The talk at Columbia is probably the only opportunity to talk about the past as a model, in his opinion, in relation to an intellectual from the Old World; it is a prime opportunity to outline the spiritual and mental condition of a European; ultimately it is a kind of proclamation of Miłosz's own literary program, clarified under the influence of experience and in the heat of disputes with his opponents. Miłosz makes use of this opportunity. He attacks both the Marxist vision of culture and the attitude of moralists trying to achieve a similar educational goal using other means, only reduced politically:

Literary quarrels and discussions are centered around this core. What I mean is a conflict between an effort to establish a socialist society on a new basis and a reluctance to render him miserable through forcing him into a mold to which he is unsuited. Man changes, but when he is compelled to change his habits and customs too quickly, he can be harmed just as young plants can be. On the other hand, there is a great unknown - his inner nature - which demands songs, music, and disinterested beauty. ${ }^{247}$

The poet goes beyond both utopias, returning to the beginning of his argument:

Man changes and literature is to be a sort of a treatise on his changing morals. But how far does the change reach? To what extent are we prone to delusions? What is the link between his past and his presence? Whoever says: morals, says: human happiness. Does a certain limit of change

246 Ibidem, pp. 11-12.

247 Ibidem, p. 11. 
exist, a limit, or a certain core of human nature, which should not be destroyed, unless we want to make Man unhappy? Man is a being full of contradictions. He loves to work and to be lazy: to concentrate and to relax; to sacrifice himself and to have his little fun. The moralists are severe people. Their zeal increases with practice of morals, in the case of moralistic writers, with the new volumes they produce. They are inclined gradually to forget that man cannot live only by duty, sacrifice, and thought about the generations to come. ${ }^{248}$

In the current discussion on literature, the speaker sees a renewal of Plato's dispute with the poets. He takes a consistent position in it, already evident in his wartime poems. A clear subtext for the defense of the autonomy of poetry in the talk at Columbia is his awareness of the tightening course of cultural policy in the country. The lecture given in April 1949 seems to be a response to the inauguration of socialist realism at the January Congress of the Polish Writers' Union. It is not a coincidence that the poet utters this words prior to his trip to Poland in May, pre-announcing his position in this matter. He continues:

\begin{abstract}
My personal observation is that the moralists of today distrust beauty as much as the Puritans distrusted Flesh. The Puritans reluctantly permitted sexual acts as a means of begetting children. The moralists agree, reluctantly, to tolerate beauty, but under the condition that beauty serves a serious purpose. They have very good reasons to distrust beauty. I have told you about our vehement refusal to accept the withered charms of pre-war literature. But perhaps that beauty was not a true one. True beauty speaks a simple language and tells us how splendid life is and how much better it is to be a man than a stone. ${ }^{249}$
\end{abstract}

Miłosz does not explain further his concept of beauty - he discusses it partly in the essays printed in Polish magazines, and then he puts it forward it in "Notatnik amerykański" [The American Notebook], arranged anew for the needs of the volume Kontynenty [Continents]. There are clear parallels between his literary output and public speaking practice; it even seems that the talks played the role of a workshop in which the poet refined his views, discussing with himself. At the end of the Columbia lecture, he utters a thought that seems to herald his future situation and foreshadow his further work. He compares writers and creators of programs to sinners and theologians, and this parallel seems understandable several years before writing The Captive Mind, in which communism is called the New Faith. The allusions in the metaphors of sinners and theologians are clear. Moreover, Miłosz, mentioning here the Dantesque practice of placing opponents in literary Hell, unambiguously suggests how he sees his future:

Since a writer has always to pay a price. Here, in this country, he pays the price by teaching at colleges and universities, by being divided from the people by the greensward of campuses or the

248 Ibidem, pp. 12-13.

249 Ibidem, p. 10. 
walls of an office. In many countries of Europe, he pays the price by being a privileged individual who is supposed to be a teacher of his nation and by bearing the burden of responsibility. That responsibility cannot be limited to the problems of his art. He has to be - to some extent - also a politician and a philosopher. To stress the analogy of passing from the Latin to the vernacular, let us remember that Dante was a theologian poet and author of political enemies in Hell. Whether we like it or not, there is no other course open to us than to put our enemies in Hell and to try to do in our new vernacular at least a part of what Dante achieved in his. (...) What I fancied to convey to you is our common belief that it is too early to expect the end of the world and that we are convinced that many generations will profit from our achievements if our hearts are pure enough. $^{250}$

Everything that was to be said was said. Nowhere else will the poet ever reveal the connection between the Traktat moralny [Treatise on Morals] and the Dantesque tradition. In no other place did he say so much about the despair of personal transformation, the effort by which he overcame the psychological effects of the occupation, what work he did to ultimately sustain his faith in the teaching duty of the writer. The lecture at Columbia is perhaps the most intimate self-presentation the poet ever made at that time, although - as usual - he made efforts to sound a tone of the generation, so that history might speak through him. He never published the lecture, although it might have cast additional light on his psychological condition at and worldview at the time, and explained partially the violent tone of the resounding "No."

There are no other archives related to the poet's speaking activity. Kridl noted that on February 27, 1950, in room 301, Philosophy Hall, at 8 PM Miłosz delivered a lecture to the Polish Philology Circle at Columbia University:

Mr. Czesław Miłosz, Polish poet and writer had a talk about "Problems of the contemporary Polish writer." He presented the situation of the writer in present day Poland in comparison with that in pre-war Poland, analyzed works of novelists, poets and playwrights and explored problems they are concerned with; furthermore he spoke on the material situation of the writers, the number of copies printed, the reaction of the public, and so on. The lecture was attended by about 30 persons..$^{251}$

However, the preserved texts of the lecture seem to illustrate the process of transformation in Miłosz's thinking about Poland and Polishness, Europe and America, East and West, the past and the future. Perhaps - in addition to Miłosz's correspondence - these are the most valuable autobiographies of an intellectual who practiced a kind of auto-pedagogy and unknowingly assumed the role of a pedagogue without limiting himself to the duties of a lecturer. It is easy to agree with Marta

250 Ibidem, pp. 14-15.

251 Kridl, Manfred: “Polish Circle (Koło Polonistów), Columbia University, Dept. of Slavic Languages.” Manfred Kridl Collection, Columbia Rare Book and Manuscript Library, Box 17, Subject File: Polish Circle (2) At Columbia. 
Piwińska when she writes: "Looking for answers to certain questions in all of Miłosz's work, I hasten to add that I understand The Captive Mind, Native Realm, The Land of Ulro, and Prywatne obowiazki [Private Obligations] also as his 'lectures on Poland for the West'."252

252 Piwińska, Marta: op. cit., p. 74. 